\title{
LONG TERM ANCHOR HOLDING CAPACITY IN SATURED CLAYS
}

\section{Résistance à long terme d'un ancrage dans de l'argile saturée}

\author{
by \\ Bing C. YEN \\ Professor, Department of Civil Engineering, California State University, Long Beach, California - USA \\ Steve J. YOUNG \\ Research Assistant, Department of Civil Engineering, California State University, Long Beach, California - USA
}

\begin{tabular}{|c|c|}
\hline SOMMAIRE & SUMMARY \\
\hline $\begin{array}{l}\text { Cette communication présente les résultats } \\
\text { d'une étude en laboratoire sur le comportement } \\
\text { du système ancrage-sol soumis à un chargement } \\
\text { de longue durée dans de l'argile saturée, normale- } \\
\text { ment consolidée. } \\
\text { Des sondes piézométriques miniaturisées enre- } \\
\text { gistrent la pression interstitielle autour de l'an- } \\
\text { crage et la dépression interstitielle (aspiration) } \\
\text { sous l'ancrage. Les résultats expérimentaux ont } \\
\text { mis en évidence des relations fonctionnelles entre } \\
\text { le déplacement de l'ancrage, la charge de l'ancrage } \\
\text { et la pression interstitielle associée au processus } \\
\text { de consolidation. }\end{array}$ & $\begin{array}{l}\text { The results of a laboratory model study inves- } \\
\text { tigating the behavior of deeply embedded anchors } \\
\text { are presented. The primary purpose of the tests } \\
\text { is to study the behavior of the anchor-soil system } \\
\text { under long-term loading in saturated, normally } \\
\text { consolidated clay. } \\
\text { The tests were conducted in soil of two diffe- } \\
\text { rent shearing strengths. For each soil strength, } \\
\text { three different long-term load tests were perform- } \\
\text { ed. Long-term loads applied were at stress } \\
\text { levels equivalent to } 25 \% \text {, } 50 \% \text { and } 75 \% \text { of the } \\
\text { short-term (undrained) anchor break-out capacity. } \\
\text { Pore pressure responses around the anchor, in- } \\
\text { cluding the negative pore pressure (suction) } \\
\text { beneath the anchor, were monitored using minia- } \\
\text { ture piezometric probes. The test results provided } \\
\text { functional relationship between anchor displace- } \\
\text { ment, anchor load and pore pressure responses } \\
\text { associated with consolidation process. }\end{array}$ \\
\hline
\end{tabular}

\section{INTRODUCTION}

Although the use of anchors to moor ships reportedly began in the Bronze Age, according to Frost (1963), significant research in an organized manner on model anchor breakout resistance did not begin until the 1930's in the United States (Howard and James, 1933; Leachy and Farrin, 1935; Lucking, 1936). Increased ocean engineering applications have, in the last two decades, increased the amount of research devoted to anchor holding capacity considerably. The research results can be broadly classified into two categories. The first category treats the anchor problem mathematically. The transformation of classical cavity expansion solutions into anchor problems represents one form of this approach, e.g., Gibson (1950) for clays; Skempton, et al (1953) for sands; Ladanyi (1959) for sands, for clay (1967), for sensitive clays (1967) and in permafrost (1974); and Vesic (1971, 1972) among others. The finite element numerical simulation represents another mathetical approach, e.g., Sandhu and Wilson (1969); Christian and Boehmer (1970); Ghaboussi and Wilson (1971); and on-going research in the Civil Engineering Laboratory of the U.S. Navy.

Although it is possible to solve some important, characteristic anchor problems with a rigorous theoretical and/or numerical solution, the time and cost required usually makes this approach prohibitive for engineering applications. In most cases, the solutions depend upon many soil factors which are only known approximately or which have to be postulated. The anchor holding capacity problem appears to be a non-conservative mechanics problem. There are theoretical difficulties in solving non-conservative mechanics problems at this time. The second category of previous research is primarily related to model tests and/or field observations. Numerous articles are available particularly for sandy soils and for on-shore projects. Only limited data are available for model tests in cohesive soils and even less for off-shore projects, Mariupolskii (1965); Adams and Hayes (1967); Meyerhof and Adams (1968); Bhatangar (1969); Bemben (1973, 1975); Colp and Herbich (1972); Meyerhof (1973) and Beard (1974). For anchors in clay, only a few had pore pressure measurements for the clay soil within which the anchors were embedded (Adams and Hayes and Beard). The authors are aware of only one, Beard (1974), that included the pore pressure measurements around the model anchor in a simulated condition of saturated submarine clayey soil.

From a practical viewpoint, a deep ocean embedded anchor in service will be under load for a long period of time. The long-term anchor-soil behavior is related to the consolidation and flow of water into or out of the soil surrounding the anchor. Consequently, the pore pressure/pore suction and the migration of pore 
water may have either a strengthening and/or weakening effect on the surrounding soil and thus influence the holding capacity of the anchor. Most deeply embedded ocean anchorages will occur in saturated normally consolidated clays. Since little is known about the pore pressure/suction response around the anchor in such soils, this aspect of the soil-anchor behavior is considered in this paper, i.e., the long-term behavior of deeply embedded anchors in normally consolidated, saturated clayey soil. Deep embedment is a condition in which the ratio of the depth of embedment to the diameter of the anchor is greater than 5 .

\section{TESTING PROGRAM}

\section{Soil conditions and equipment used}

The soil used is a low plastic clay (CL/ML, according to the Unified Soil Classification System) which has a liquid limit of $23 \%$ and plastic index of 6 . To insure into the soil after they had been filled with deaired water. The pore pressures were monitored by differential pressure transducers and recorded on strip-chart recorders. Soil consolidation is monitored by pore pressure probes. When the measured pore pressure is

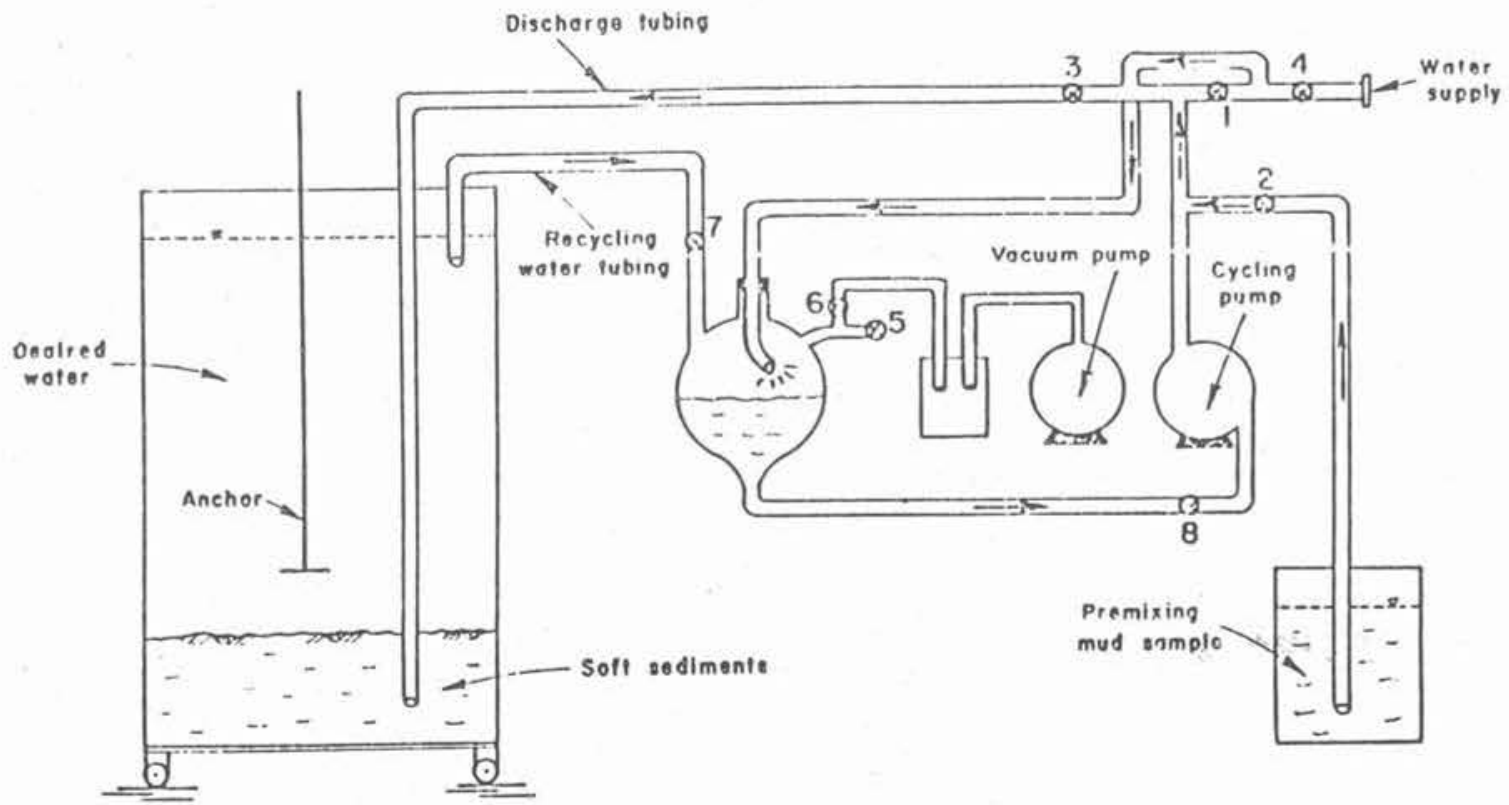

Fig. 1. - Schematic diagram showing sample preparation system.

complete saturation, special mixing equipment is necessary. A vacuum apparatus and the general test set-up are schematically shown in figure 1 , in which soil is mixed with water to provide a deaired slurry. The slurry is then consolidated under its own weight or surcharged in a consolidation bin. Another apparatus used is a modified concrete mixer in which soil is mixed at $29 \% \pm$ moisture content under vacuum then consolidated under its own weight. The soil strength profiles in which the anchor tests were performed are shown in figure 2 .

A disk-like stainless steel anchor with built-in piezometric probe(s), figure 3, was embedded in the consolidation bin. The consolidation bin has an elastic lining to decrease side friction. "Wicks" were installed to accelerate consolidation by radial drainage. Pore pressure response was monitored by stainless steel piezometric probes which have a 0.035 inch $(0.089 \mathrm{~cm})$ I.D. and $0.065(0.1588 \mathrm{~cm})$ O.D. Two side ports were cut in the closed end probe and the probes were inserted

Fig. 2. - Vane shear strength vs. depth (1": $2.54 \mathrm{~cm} ; 1$ psf: $47.9 \mathrm{~N} / \mathrm{m}^{2}$ ).

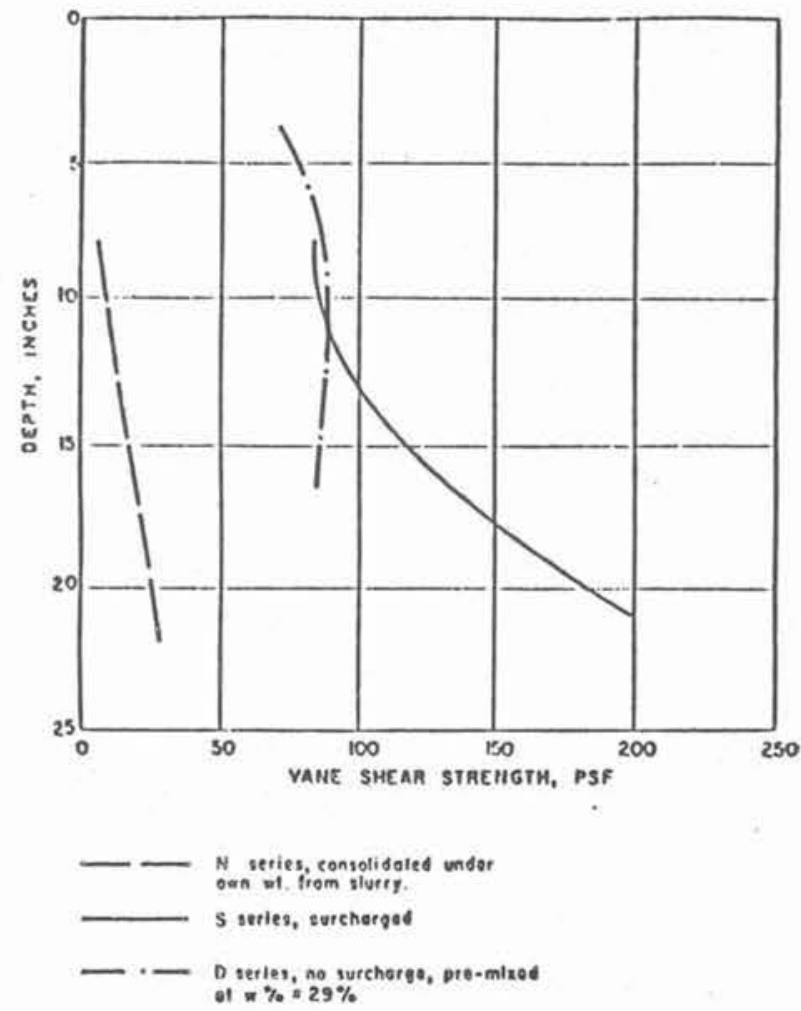


equal to the hydrostatic head of the soil in the consolidation bin, a state of normal consolidation is reached. An average of 2 to 3.5 weeks was usually required for complete consolidation, i.e. excess pore pressure less than 0.005 psi which is the limit of the pore pressure monitoring system.

\section{Test results}

Table 1 shows the types of model tests performed. speaking, the quality of test data varies according to the percent of the short term failure load applied. The best quality data is at $75 \%$ of the short-term failure load, for which significant changes in pore pressures and displacements were recorded. The data at $25 \%$ of short term failure loads are generally too small and are not very consistent. Consequently, only NL-3/4, SL-3/4 and DL-3/4 have been selected for a thorough analysis. Testing results from NL-1/2 are included in the analysis where appropriate.

TABLE 1

Model tests performed

\begin{tabular}{|c|c|c|c|c|}
\hline Soil $\begin{array}{c}\text { Testing } \\
\text { Condition }\end{array}$ & $\begin{array}{c}\text { Short-Term } \\
\text { Capacity }\end{array}$ & \multicolumn{3}{|c|}{ Long-Term Tests $\left(^{*}\right)$} \\
\hline $\begin{array}{l}\quad \text { N-Series } \\
\text { Consolidated Under } \\
\text { Own Wt. from Slurry }\end{array}$ & NQ & NL-1/4 & $\mathrm{NL}-1 / 2$ & NL-3/4 (*) \\
\hline $\begin{array}{l}\quad \text { S-Series } \\
\text { Consolidated Under } \\
\text { Surcharge from } \\
\text { Slurry }\end{array}$ & SQ & SL-1/4 & SL-1/2 & SL-3/4 \\
\hline $\begin{array}{l}\text { D-Series } \\
\text { Consolidated Under } \\
\text { Own Wt. at ave. W\% } \\
=29 \%\end{array}$ & $\mathrm{DQ}$ & $-\cdots$ & $\cdots-$ & DL-3/4 \\
\hline
\end{tabular}

(") Long-term tests under $1 / 4,1 / 2$ and $3 / 4$ of Short-Term holding capacity; e.g. NL-3/4 indicates a long-term test under a load equal to $3 / 4$ of short-term anchor capacity in a soil which was consolidated from slurry under its own weight.

A short term capacity test is defined as one in which virtually undrained soil conditions exist during incremental loading until the anchor is pulled out. Once the short term capacity for each testing series is determined, long-term tests with loads equal, $1 / 4$, $1 / 2$ and $3 / 4$ are performed and they are designated as shown in table 1 .

"N» and «S" series tests were performed with a $3 "(7.62 \mathrm{~cm})$ diameter anchor (fig. 3) while the «D» series was performed with a $1.75^{\prime \prime}(4.45 \mathrm{~cm})$ diameter anchor.

Large pore pressure responses and significant displacements were recorded during the NL-3/4, SL-3/4, and DL-3/4 tests. However, as would be expected, when the load applied to the anchor decreases, both the displacement of the anchor and pore pressure response in the surrounding soil decrease as well. In terms of displacement, NL-1/2 is approximately $1 / 10$ that of NL-3/4 while NL- $/ 4$ displacement is only $1 / 25$ that of NL-3/4. The total displacement of NL-3/4 is $1 / 2$ inch $(1.27 \mathrm{~cm})$. For the surcharge (S-Series) model tests, the displacement for $\mathrm{SL}-1 / 2$ is only $1 / 250$ of that for SL-3/4 and SL- $1 / 4$ displacement data is too small and erratic to be consistent with the other two. The total displacement of $\mathrm{SL}-3 / 4$ is about 2.5 inches $(6.35 \mathrm{~cm})$. Generally

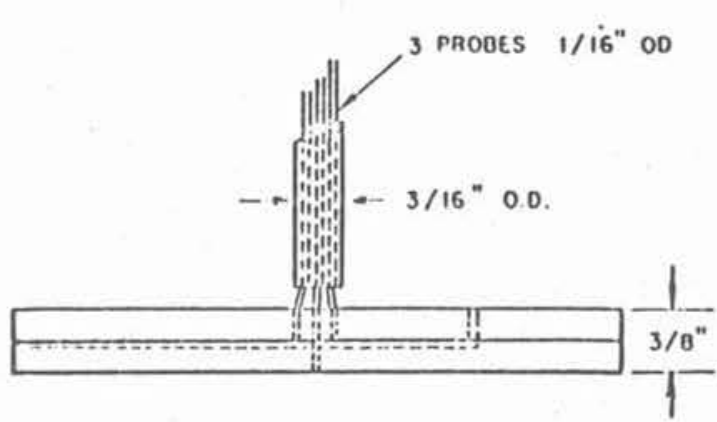

Fig. 3. - Anchor model.

The test results are analysed in terms of dimensionless parameter so that preliminary generalized conclusions can be made regarding the soil-anchor behavior during loading.

\section{Pore pressure versus displacement}

The pore pressure (U) is normalized by the average anchor contact pressure (P) (load divided by anchor 
2

1

B. 1

日. 2

4.3

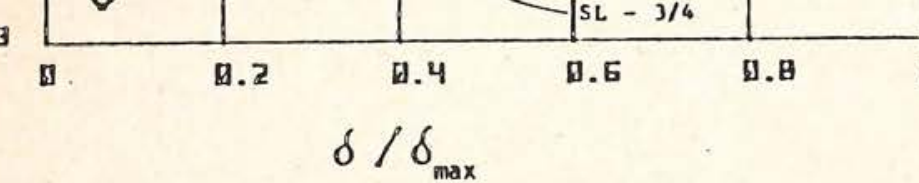

Fig. 4. - Normalized pore pressure responses vs. normalized anchor displacement for $75 \%$ short term holding capacity.

area). The corresponding anchor displacement is normalized by the total displacement $(\delta \max )$ for the given test. For example, figure 4 is a representative plot of normalized pore pressure $(\mathrm{U} / \mathrm{P})$ vs. normalized displacement $\left(\delta / \delta_{\text {m }}\right)$ for the probe located on the bottom surface on the anchor. This probe consistently measured the largest negative pore pressure (or pore suction) during all short and long term tests. The pore pressure responses in the surrounding soil corresponding to different anchor displacements, is shown in figure 5 with the use of normalized pore pressure contours. The continuous shifting, expanding and contracting of the pore pressure responses shown in figure 5 demonstrates the complexities in the soil response for an anchor under long term loading. It will be a formidable task to develop a complete solution which describes this phenomenon. Instead, a simplified mathematical model which is needed for practical engineering applications will be presented in the Analysis section.

Fig. 5. - Normalized pore pressure contours is anchor displacement ratio for $\mathrm{NL}-3 / 4$.
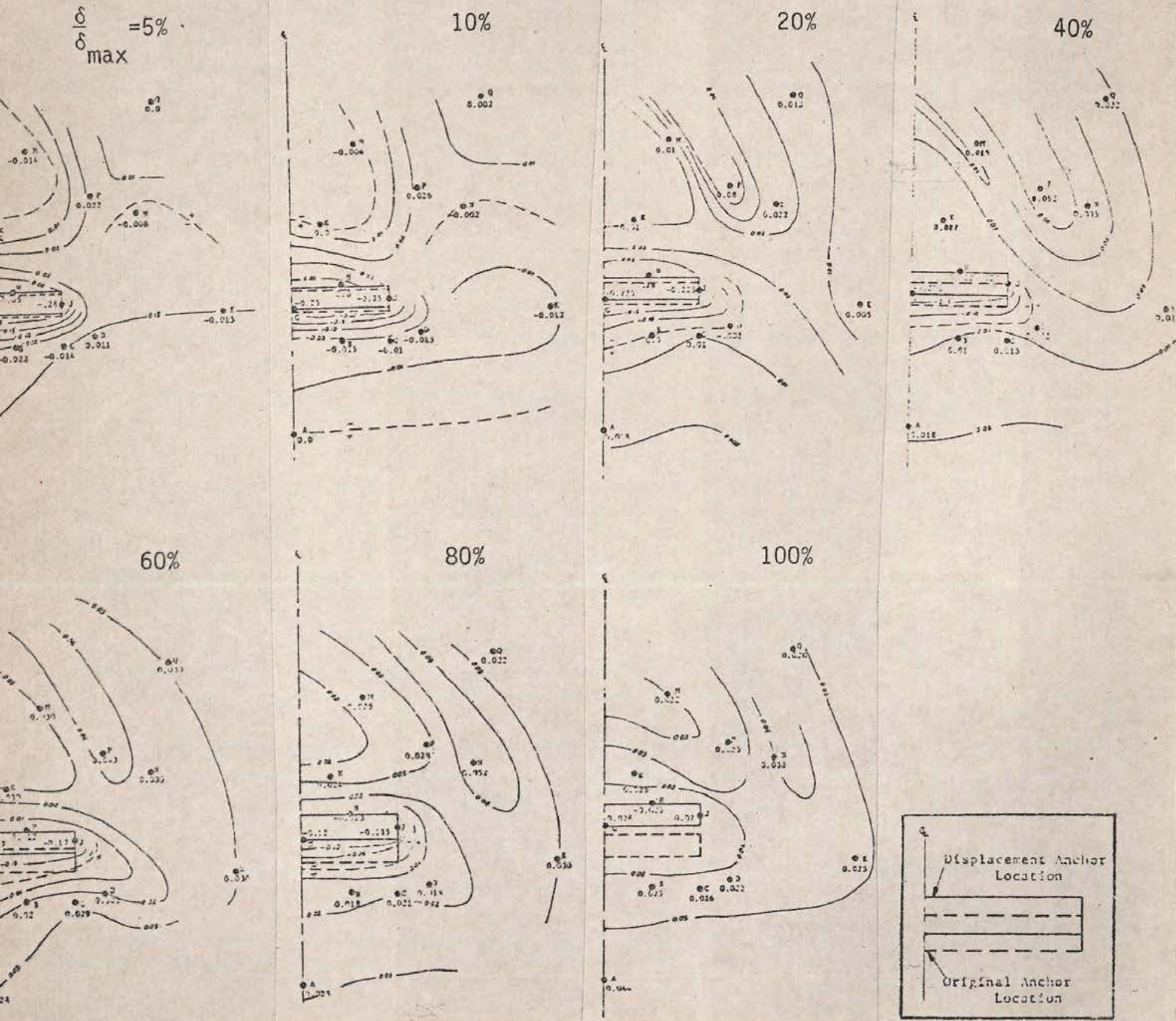


\section{Displacement vs. time}

The rate of displacement $(\delta)$ is plotted against the $\log$ of time in figure 6 (a). There is a distinct break for all long term tests which indicates the possible existence of a two-stage mechanism. The time at which the break occurs is referred to as the critical time $(t c)$. If the displacement rate is normalized by the anchor diameter and the time is normalized by the critical time $(t c)$ corresponding to each test, the set of curves shown in figure $6(\mathrm{~b})$ is obtained. The two stages are $t / t c<1$ and $t / t c>1$. For the NL-3/4 test stage 1 lasted approximately $3 \times 10^{4}$ seconds which corresponds to $\delta / \delta_{\max }$ equal to about $80 \%$ in figure 5 . Both local shear and consolidation appear to dominate in this stage. For stage 2 , where $t / t c>1$, relatively small pore pressure response is observed and soil creep seems to dominate. Thus, the difference between the short term failure and long term holding capacity depends on whether stage 2, soil creep develops, or whether stage 1 accelerates to failure, In either case, there appears to be a conical zone of large shear strain existing above the anchor with relatively small pore pressure change, suggesting that a localized critical state may have been reached, (Schofield and Wroth, 1968; Yen, 1977).

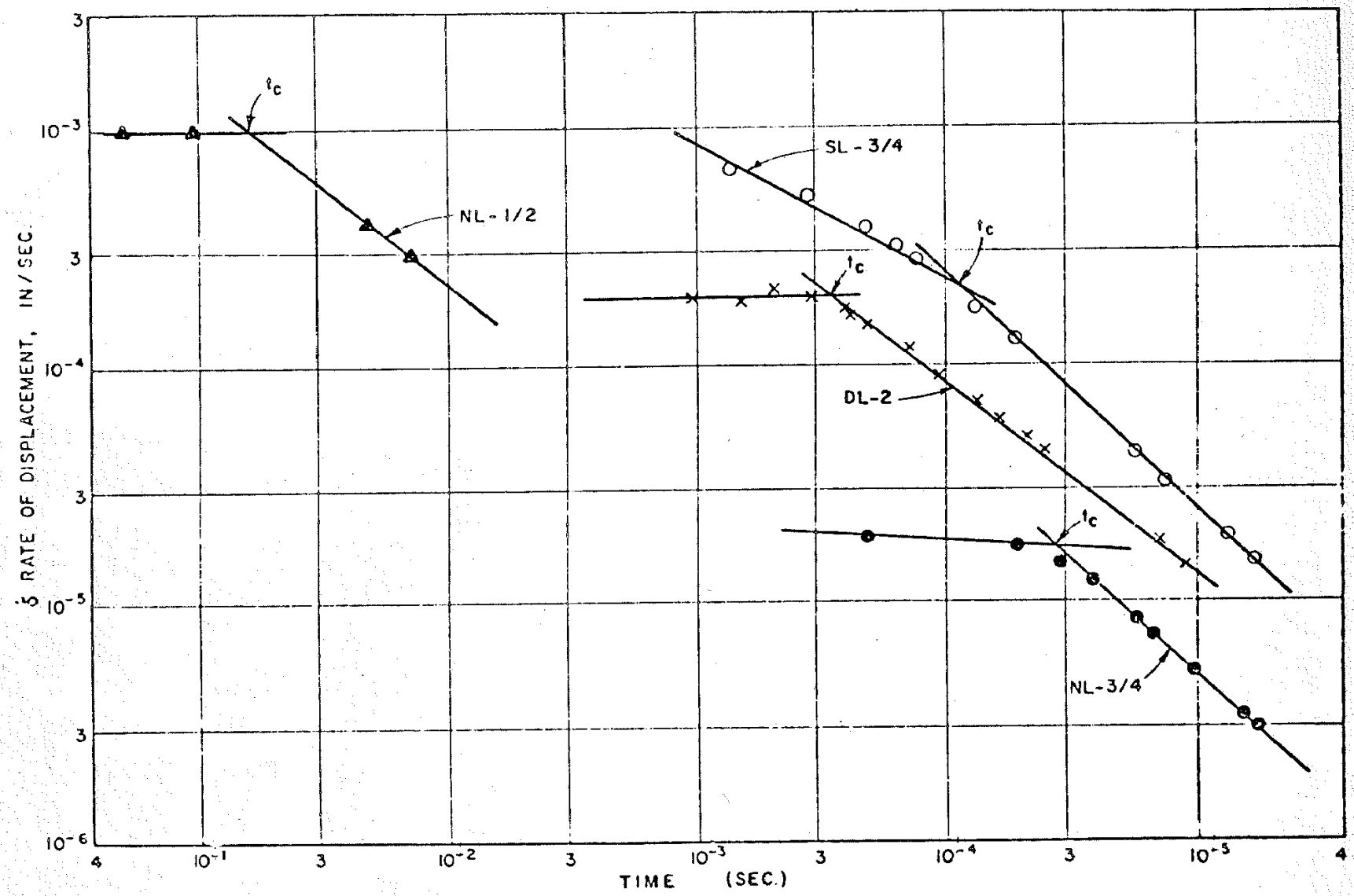

Fig. $6 \mathrm{a}$ - Rate of displacement vs. time elapsed, long term tests.
Fig. 6 b. - Logarithmic strain vs. $t / t_{c}$.

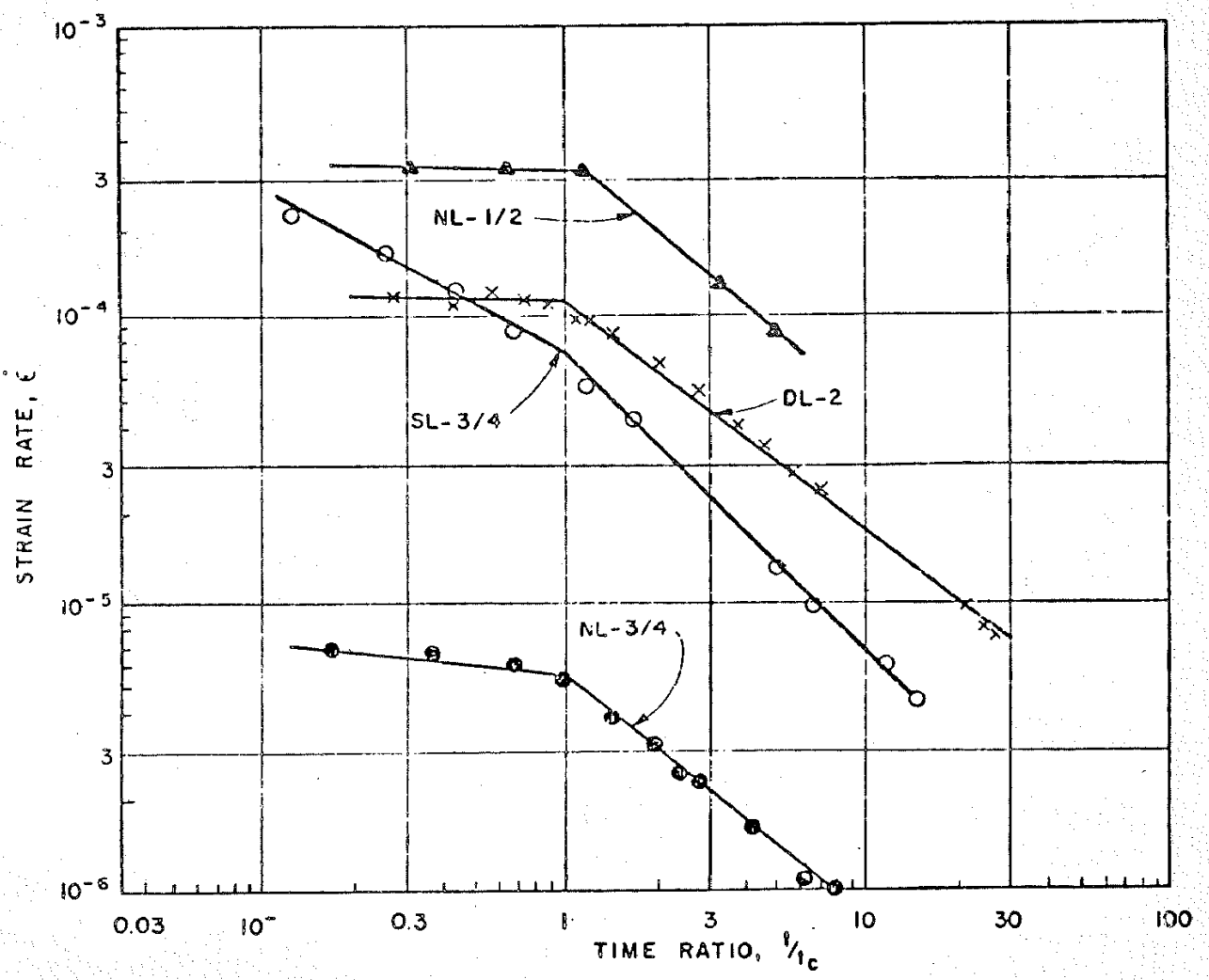




\section{ANALYSIS}

There are primarily four sources of resistance that act together to resist the anchor load: (1) pore suction beneath the anchor; (2) pore pressure above the anchor; (3) the mobilized soil strength and (4) the adhesion along the side of the anchor and the resistance of soil due to rotation of principal stresses. Among them, the adhesion and stress rotation are difficult to assess but they are believed to be secondary because the anchor used is thin and the soil has a soft consistency. Figure 7 shows the relative magnitudes of the three primary resisting forces with respect to the time elapsed. Pore pressure and suction measured at upper and lower anchor surfaces are normalized by the anchor contact pressure $\mathrm{P}_{c}$. The pore pressure and suction are added and plotted on the vertical axis of figure 7 in percentage of $\mathrm{P}_{c}$. Thus the remaining percentage of resistance to the anchor uplift must be due to soil resistance. It can be seen that pore suction and pore pressure constitute respectively about $25 \%$ and $5 \%$ of total resistances during the early stage of the long term loading. Figure 7 also shows that the mobilized soil resistance increases with time. As time elapsed approaches $t_{c}$, almost all the anchor resistance is derived from soil strengths. In the mean time, almost all the excess pore pressure above the anchor has dissipated suggesting consolidation is near completion. Equilibrium is reached where there is no further anchor movements, i.e., the maximum drained strength of the soil acting on an unknown but most likely conical surface (Berezantsev, 1956; Colp and Herbrich 1972; Ali, 1968; Johnston and Landanyi, 1974) above the anchor brings about the equilibrium state Based on this observation, a simplified anchor model is proposed, figure 8

$$
\mathrm{L}=\mathrm{P}_{\mathrm{N} f} \cdot \tan \Phi_{f}^{\prime} \cdot \mathrm{A}_{u}
$$

in which $\mathrm{L}$ is anchor uplift load; $\mathrm{P}_{\mathrm{N} f^{\prime}}$ is the effective normal pressure acting at cone surface, $\mathrm{A}_{u}$; and $\Phi^{\prime}{ }_{f}$ is the soil effective angle of internal friction. The $\Phi^{\prime}{ }_{t}$ value for normally consolidated clay can be estimated from the plasticity index, e.g., Lambe and Whitman,

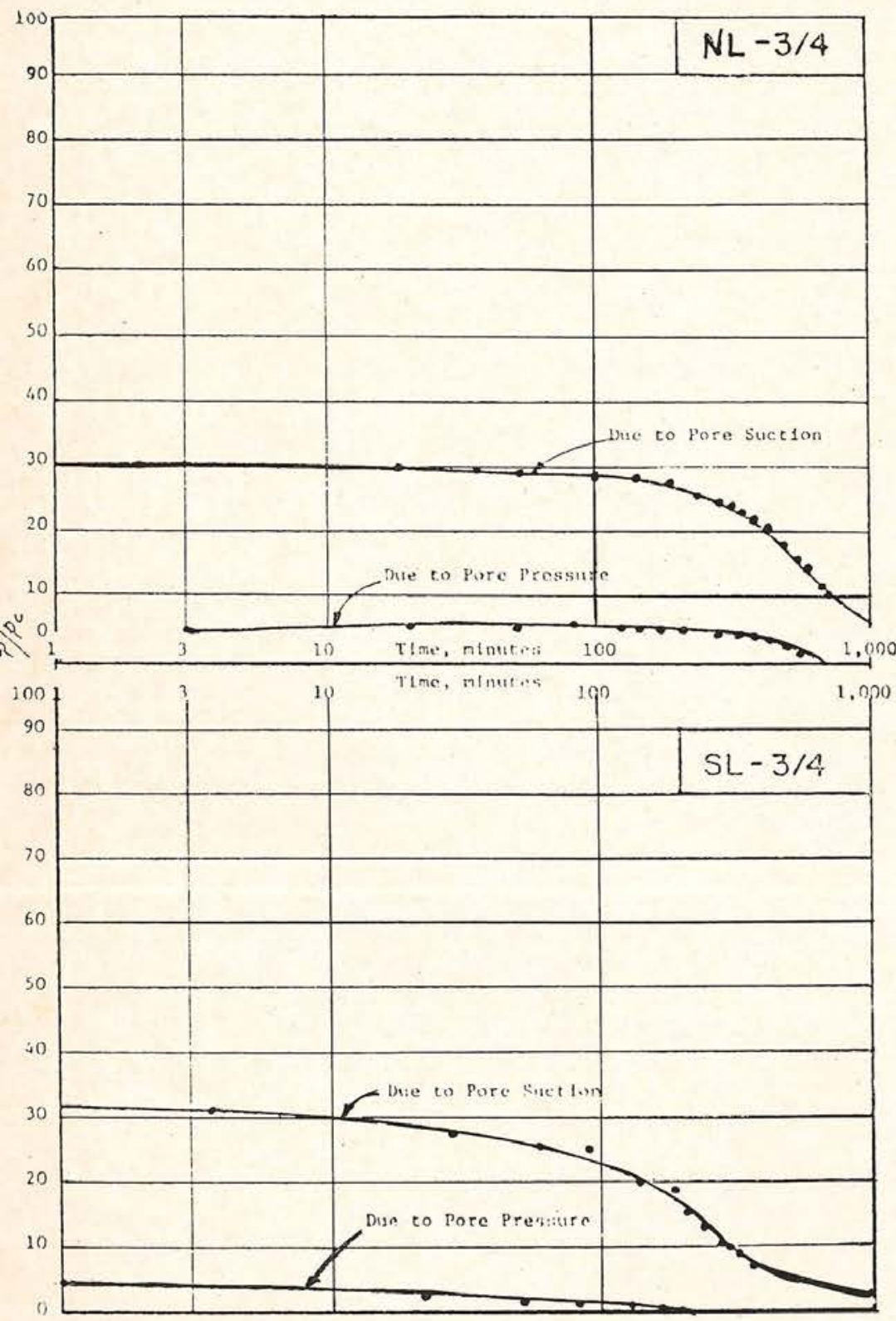

Fig. 7. - Relative magnitude of resisting forces to anchor loads vs. time.

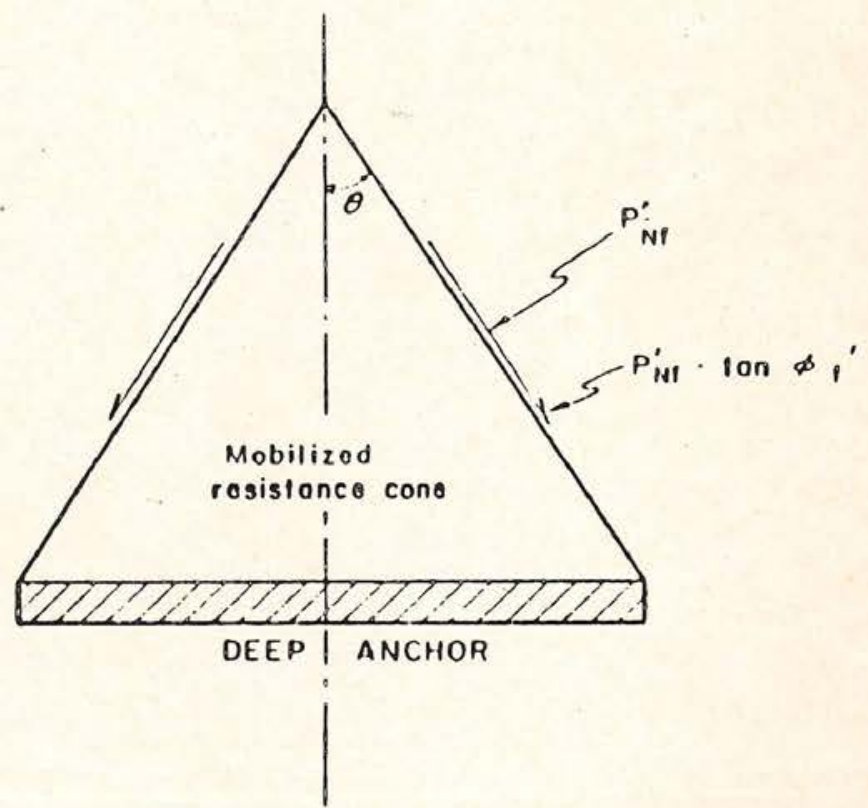

Fig. 8. - Schematic sketch showing simplified anchor failure model. 


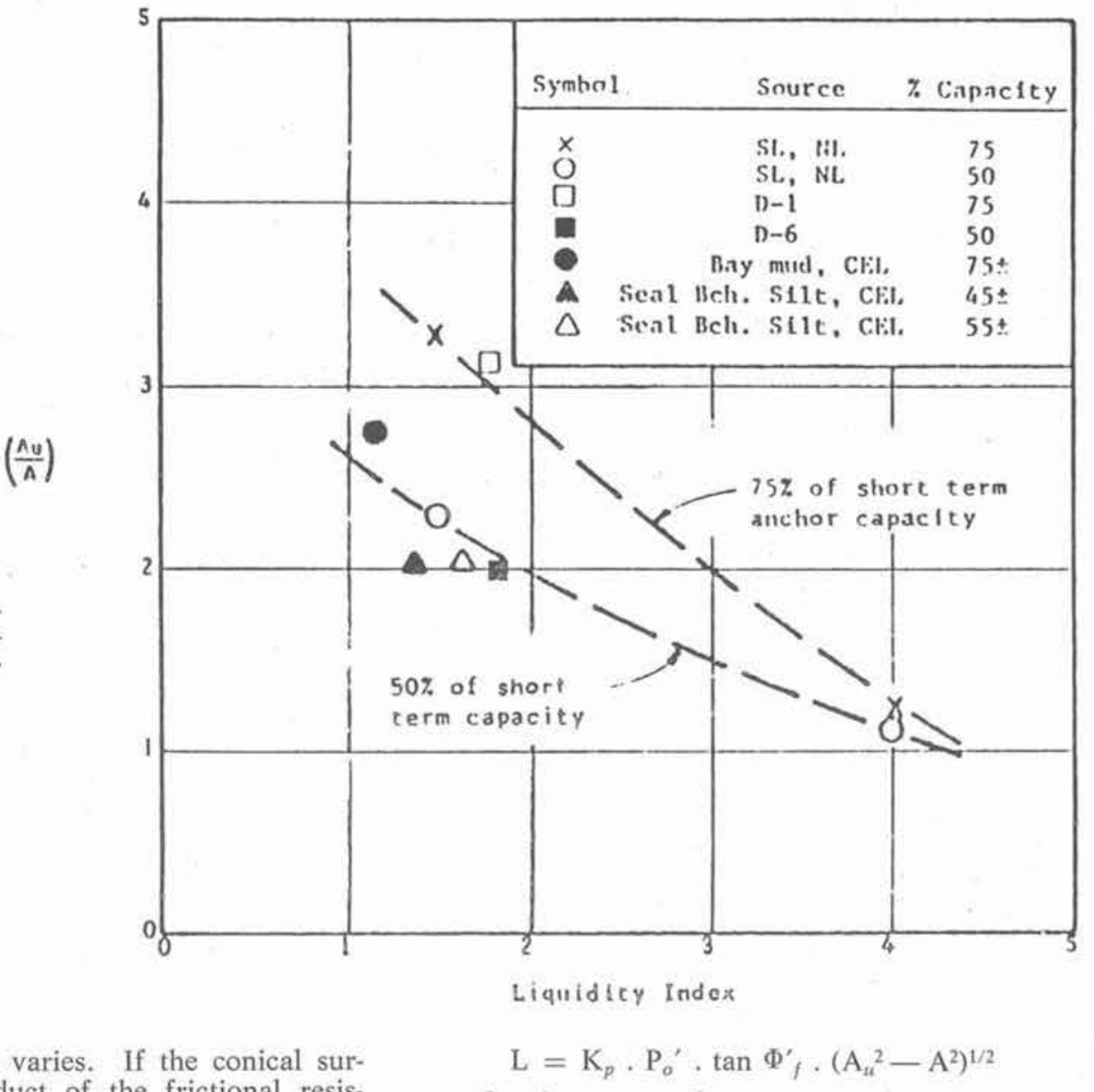

Fig. 9. - Relationship between liquidity index and ra. tio of mobilized cone surfaces.

1969. The conical surface varies. If the conical sur-
face is too small the product of the frictional resistance $\left(\mathrm{P}_{\mathrm{N} f} \cdot \tan \Phi_{f}^{\prime}\right)$ and $\mathrm{A}_{u}$ is less than the anchor load, a greater conical surface has to be mobilized until the product of frictional resistance and the enlarged $\mathrm{A}_{u}$ is equal to the anchor load. This mobilizing process exhibits itself qualitatively in figure 5. During this process, the soil consolidates and shears under large strain due to the ascending anchor. Consequently, the conical surface of figure 8 advances against the resistance, $\mathrm{P}_{\mathrm{N} i}{ }^{\prime}$ due to soil overburden, $\mathrm{p}_{o}$. $\mathrm{P}_{\mathrm{N} i}$ may be approximated by the passive resistance

$$
\mathrm{P}_{\mathrm{N} f}^{\prime}=\mathrm{K}_{p} \cdot \mathrm{P}_{o}^{\prime} \cdot \cos \theta
$$

in which $\mathrm{K}_{p}$ is the coefficient of passive pressure.

Combining equations (1) and (2) and noting that $\mathrm{A}_{u}=\frac{\mathrm{A}}{\sin \theta}$ in which $\mathrm{A}$ is the circular area of the anchor, the long term anchor load can be expressed as follows:
Or, in terms of average anchor contact pressure $\mathrm{P}=\frac{\mathrm{L}}{\mathrm{A}}$,

$$
\mathrm{P}=\mathrm{K}_{p} \cdot \mathrm{P}_{o}^{\prime} \cdot \tan \Phi_{f}^{\prime} \cdot\left(\frac{\mathrm{A}_{u}{ }^{2}}{\mathrm{~A}^{2}}-1\right)^{1 / 2}
$$

For the tests performed, all terms of equation (4) are known except $\mathrm{A}_{u}$.

Figure 9 shows the relationship of $A_{u}$ as a function of soil liquidity index. It can be seen that $\mathrm{A}_{u}$ increases with the stiffness of the soil and increases with the magnitude of the load applied. Figure 9 also shows data from prototype tests performed by the Civil Engineering Laboratory of the U.S. Navy that check satisfactorily with this study. Although additional studies are needed to further define $\mathrm{A}_{u} / \mathrm{A}$, equation (4) appears to provide an engineering estimate on anchor holding capacity under long term load.

\section{CONCLUSIONS}

1) There are two distinct stages of soil-anchor interaction under long term loading. The parameters in the relationship of $\mathrm{U} / \mathrm{P}$ versus $\delta / \delta_{\max }$ appear to be significant in describing this phenomena.

2) For the soil tested at liquidity index greater than 1 , there is no evidence indicating that the long term capacity is smaller than short term capacity.
3) A simplified mathematical model has been developed to provide an engineering estimation for the long term anchor load in normally consolidated clay. This model involves the effective angle of internalfriction and depends on liquidity index. The model compares well with anchor performance in field studies.

\section{ACKNOWLEDGEMENT}

This study was supported by the Civil Engineering Laboratory (CEL) of the U.S. Navy. Mr. R. M. Beard of CEL participated in the discussion and provided field testing results. Mr. Tony Vandagriff, formerly a technician at California State University, Long Beach contributed in developing the testing equipment. 


\section{REFERENCES}

[1] ADAMS (J.I.) and HAYES (D.C.). - «The Uplift Capacity of Shallow Foundations», Ontario Hydro Research Quarterly, 1st Quarter (1967).

[2] ALI (M.S.). - «Pullout Resistance of Anchor Plates and Anchor Piles in Soft Bentonite Clays», Duke University, Soil Mechanics Series No 17 (1968).

[3] BEMBEN (S.M.), KUPFERMAN (M.) and KALAGIAN (E.H.). - «The Vertical Holding Capacity of Marine Anchors in Sand and Clay Subjected to Static and Cyclic Loadings», CEL contracted report N 62399-70-0025, University of Massachusetts (1972).

[4] BEMBEN (S.M.) and KUPFERMAN (M.). «The Vertical Holding Capacity of Marine Anchor Flukes Subjected to Static and Cyclic Loading», Offshore Technology Conference, paper No 2185 (1975).

[5] BEARD (R.M.). - «Development of an Expedient Site Investigation Tool and Investigation in Long-Term Holding Capacity», CEL Report, Port Hueneme, California (May 1974).

[6] BEREZANTSEV (V.G.). - «Bearing Capacity of Foundations at an Axially Symmetric State of Stress», Proc. Conf. Soil Mech. Found. Engr., Gostroyizdat, Moscou, USSR, p. 84 (1956)..

[7] BHATANGAR (R.S.). - «Pullout Resistance of Anchors in Silty Clays», Duke University, Soil Mechanics Series No 18 (1969).

[8] CHRISTIAN (J.T.) and BOEHMER (J.W.). «Plane Strain Consolidation by Finite Elements», Journal of Soil Mechanics and Foundations Div. ASCE, Vol. 96, p. 1435 (1979).

[9] COLP (J.L.) and HERBRICK (J.B.). - «Effects of Inclined and Eccentric Load Application on the Breakout Resistance of Objects Embedded in Sea Floor", COE Report 153, Sandia Laboratories, Albuquerque, New Mexico (May 1972).

[10] FROST (H.). - «Under the Mediterranean Marine Antiquities», Prentice-Hall, Englewood Cliffs, New Jersey, p. 278 (1963).

[11] GHABOUSSI (J.) and WILSON (F.L.). «Flow of Compressible Fluids in Porous Elastic Media», UC-SESM Report No 71-72 (1971).

[12] GIBSON (R.E.). - Discussion, Journal 4 Inst. of Civil Eng., Vol. 34, p. 382 (1950).

[13] HOWARD (W.E.) and JAMES (R.K.). - «Investigation of Anchor Characteristics by Means of Models», Massachusetts Institute of Technology (1933).

[14] JOHNSTON (G.H.) and LACANYI (B.). «Field Tests of Deep Power-installed Screw Anchors in Permafrost», Canadian Geotechnical Journal, Vol. 11, No 3, p. 348 (Aug. 1974).

[15] LADANYI (B.), - «Deep Punching of Sensitive Clays», Proc. 3rd Panam. Conf., Soil Mech. Found. Engrg., Caracas, Venez., Vol. 1, p. 535 (1967).
[16] LADANYI (B.) and JOHNSTON (G.H.). "Behavior of Circular Footings and Plate Anchors Embedded in Permafrost», Can. Geotech. Jour., Vol. 11, No 4, p. 531 (1974).

[17] LADANYI (B.). - «Etude Théorique et Expérimentale du Problème de l'expansion dans un sol Pulvérulent d'une Cavité Présentant une Symétrie Sphérique ou Cylindrique», Ph.D. Thesis, University of Louvain, Louvain, Belgium (1959).

[18] LAMBE (T.W.) and WHITMAN (R.V.). - «Soil Mechanics», John Wiley and Sons, p. 443 (1969).

[19] LEACHY (W.H.) and FARRIN Jr. (J.M.), «Determining Anchor Holding Power from Model Tests», Transactions, Society of Naval Architects and Marine Engineers, Vol. 43, p. 105 (1935).

[20] LUCKING (D.F.), - "The Experimental Development of Anchors for Seaplanes», Transactions, Institution of Naval Architects, p. 201 (1936).

[21] MARIUPOLSKII (L.G.). - «The Bearing Capacity in Anchor Foundations», Soil Mechanics and Foundation Engineering (translated from Russian), by Consulting Bureau, No 1, p. 26 (1965).

[22] MEYERHOFF (G.G.). - «The Uplift Capacity of Foundations Under Oblique Loads», Canadian Geotechnical Journal, Vol. 10, No 1, p. 6 (Feb. 1973).

[23] MEYERHOFF (G.G.) and ADAMS (T.I.). "The Ultimate Uplift Capacity of Foundations», Canadian Geotechnical Journal, Vol. 5, p. 225 (1968).

[24] SANDHU (R.S.) and Wilson (E.L.). - «Finite Element Analysis of Flow in Saturated Porous Elastic Media», Journal of Engineering Mechanics Division, ASCE, Vol. 95, p. 641 (1969).

[25] SKEMPTON (A.), YASSIN (A.A.) and GIBSON (R.E.). - «Théorie de la Force Portante des Pieux dans le Sable», Annls. Inst. Tech. Bat, Trav. Publ., 63/64, p. 285 (1953).

[26] VESIC (A.S.). - «Breakout Resistance of Objects Embedded in Ocean", Journal of Soil Mechanics and Foundations Division, ASCE, Vol. 97, No SM 9, p. 1183 (sept. 1971).

[27] VESIC (A.S.). - «Expansion of Cavities in Infinite Soil Mass», Journal of Soil Mechanics and Foundations Division, ASCE, Vol. 98, No SM 3, p. 265 (March 1972).

[28] YEN, BING (C.). - «Deep Anchor Long Term Model Tests», Contract Report CF 76.0003, Civil Engineering Laboratory, U.S. Navy, Port Hueneme, California, National Technical Information Service Publication, No ADA022142, (Dec. 1976).

[29] YEN, BING (C.) -- «Response of Embedded Model Anchor to Cyclic Line Loading», Interim Report for Contract N68305-76-C-0031, Civil Engineering Laboratory, U.S. Navy, Port Hueneme, California (April 1977). 